\title{
Multiple Forms of Professional Agency for (non)crafting of Work Practices in a Hospital Organization
}

\author{
I Kaija Collin' \\ University Researcher, University of Jyvaskyla, Finland
}

I Susanna Paloniemi

University Lecturer, University of Jyvaskyla, Finland

I Katja Vähäsantanen

Postdoctoral Researcher, University of Jyvaskyla, Finland

\begin{abstract}
In recent working life studies, professional agency is seen as pivotal to the development of work communities and work organizations. This paper addresses professional agency during a practicebased intervention (work conference) in a Finnish hospital setting. To develop work practices, the intervention sought to create a dialogical space for the promotion of collective professional agency. Here, we present an investigation of the manifestations of professional agency and how they emerged within and between professional groups. We also elaborate how professional positions frame the emergence of different manifestations of professional agency. The audio and video materials from the intervention are analyzed through the utilization of qualitative content analysis and analysis of key incidents illustrating the emergence of professional agency and its connection to prevailing circumstances in a hospital work context. Transformative, responsive, relational, and resisting forms of agency were identified. The emergence of these forms differed amid the intervention and across the professional groups, reflecting power relations in the organization. In light of the findings, we discuss the meaning of different forms of professional agency for developmental efforts and how professional agency may trigger or hinder sustainable organizational development.
\end{abstract}

\section{KEY WORDS}

Professional agency / work conference / ethnography / emergency unit

DOI

10.19154/njwls.v5i3a.4834

\section{Introduction}

lobal competition has led to structural reforms and to a new management culture that means tightened accountability, decreased professional autonomy, and higher employee workload (Bandura, 2002; Sohlberg et al., 2007). As a consequence of these changes, employees are arguably in danger of losing their professional agency and creativity in the heat of the managerial and power structures of working life (Brown et al.,

\footnotetext{
${ }^{1}$ Kaija Collin, Department of Education, University of Jyvaskyla, P.O. Box 35, FI-40014 Jyvaskyla, Finland, E-mail: kaija.m.collin@jyu.fi
} 
2007; Buch \& Andersen, 2013; Hökkä \& Vähäsantanen 2014). Thus, there is a need to address the challenges of working life in ways that allow employees to maintain and develop their possibilities as more autonomous subjects than they are under the current regime (Hasle \& Sørensen, 2013). It is further argued that, in order to be successful, developmental efforts and the generation of workplace innovations, for instance, require equality, dialogue-oriented operative logics, and local implementation (Alasoini, 2011; Hökkä \& Eteläpelto, 2014; Kira et al., 2010). To help meet these requirements, in this study, we investigate the manifestations of professional agency in the context of practice-based intervention (a work conference) implemented in a hospital context. We reveal how forms of professional agency are manifested within and between professional groups. Informed by a practice-based approach (see, e.g., Erden et al., 2014; Gherardi, 2012; Hager et al., 2012), we utilize the multifaceted data collected during the intervention. In particular, we address and discuss how the manifestations of agency are intertwined with organizational development in terms of fostering or hindering the development of work practices and organizations. We are also interested in how these manifestations are framed by the professional positions that are present in an organization. We focus on a hospital organization because of its complex nature in terms of status and power hierarchies and the challenges to collaborative practices (see, e.g., Pisano et al., 2001).

Recent studies on work-related learning have shown that employees, work communities, and/or organizations are the prime actors in the maintenance and enhancement of learning at work, including crafting work practices (Billett, 2011; Harteis \& Goller, 2014; Kira et al., 2010; Wrzesniewski \& Dutton, 2001). Likewise, the construction of professional identity becomes essential for employees' sense making, especially individuals' sense of meaningful work (Buch \& Andersen, 2013). This highlights the need to apply (at both the individual and community level) the concept of professional agency for the research and promotion of sustainable learning and development in work organizations. Professional agency can be understood as the exertion of influence, the making of choices, and the adoption of stances in ways that affect individuals' work and/or their professional identities (Eteläpelto et al., 2013). In the framework of this conceptualization, we address professional agency in particular as a phenomenon for fostering and hindering the development of work practices.

It is especially vital to deal with professional agency and its promotion in relation to professional positions in a hospital context because from the point of view of collaborative practices and the exercising agency, hospitals are a particularly challenging context for many reasons (see, e.g., Glouberman \& Mintzberg, 2001). Many of the constraints on the exercise of agency and on learning in hospital organizations have been found to be social (Collin et al., 2008; Ramanujam \& Rousseau, 2006) and managerial (Carter, 2002; Mintzberg, 2012) in nature, rather than clinical or technical. Previous studies (Collin et al., 2010; Lingard et al., 2004; Pisano et al., 2001) have indicated that the individual and technical nature of the work, status, and power hierarchies and unshared knowledge, deficient information flow, and the instability of the composition of teams are barriers to collaborative practice and learning across professional boundaries. Physicians are obviously in the decisive position because of their legal status concerning responsibility for patients and cures and are therefore higher in the official hierarchy. Nurses and secretaries seem to have less power to make final decisions related to cures because of their lower hospital status. Moreover, the distinct professional identities are

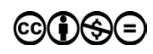


bounded by a culture that has traditionally and persistently been hierarchical and noncollaborative in hospital settings (Collin et al., 2011; Paloniemi \& Collin, 2010). Thus, fundamentally cooperative and more holistic managerial practice in hospitals is called for (Mintzberg, 2012). The strengthening of collaborative and inter-professional practices in healthcare and hospitals would therefore seem to be a complex but important task. There is a need to support employees' and organizations' practice of professional agency in ways that make it possible to advance the cultivation of inter-professional practices and professional identities. In the face of this challenge, a practice-based intervention in this study was carried out to investigate the manifestations of and frames for professional agency in a Finnish hospital setting.

\section{Theoretical Standpoints}

\section{Professional agency in work-related practices and interventions}

Our conceptualization of professional agency is informed by a subject-centered sociocultural approach (Eteläpelto et al., 2013). This approach includes the idea that professional subjects are active and self-creative with their specific individual backgrounds (e.g., professional experiences), despite the fact that the practice of their professional agency is bound up in the sociocultural conditions of the workplace, including its practices, power relations, discourses, and subject positions. In this study, we address professional positions in relation to the exercise of professional agency.

Professional agency can be directed at different work-related phenomena, such as professional practices and identities (Eteläpelto et al., 2013). It can be manifested in various kinds of individual and collective actions, which can be discursive (Ahearn, 2001), mental, social, or embodied (Billett \& Pavlova, 2005; Clegg, 2006; Fenwick, 2006). Individual agency is fundamental in the renegotiation of professional identities. Professional agency can also maintain existing professional interests, goals, and ideals (Vähäsantanen \& Eteläpelto, 2011). Collective agency is needed for employees to build a shared understanding concerning the creation of new work practices, the development of work content, and the transformation of organizations, as well as the introduction of creativity and innovation at work (Forsman et al., 2014). Professional agency can manifest itself, for instance, as suggestions for new work practices and new inter-professional work strategies (Collin et al., 2010, 2012). However, much of our routine activities in the workplace require practical innovativeness, which sometimes also means maintaining existing practices (cf. Hitlin \& Elder, 2007). Strong individual agency can also hinder organizational development, particularly when it is exercised to maintain existing work practices (Hökkä \& Eteläpelto, 2014). All of this implies that professional agency can be observed to both reproduce and transform professional structures and practices (Tomlinson et al., 2013; Vähäsantanen et al., 2009).

If the practice of professional agency can maintain current work practices and structures, it is important to recognize the particular concrete actions and voices that encourage innovativeness and development in work organizations. Furthermore, it is important to recognize specifically the constructive ways in which professional agency is manifested. Here, we address the manifestations of professional agency in the context of intervention aiming to create collective and dialogical spaces for organizational development. 
Although scholars have suggested that interventions to trigger work-related learning should be created to purposefully enhance individual and collective agency (Engeström, 2011; Eteläpelto et al., 2014), we have a lack of understanding of the different manifestations of agency and their variable meanings for organizational development within interventions. One exception is Engeström (2011), who examined participants' agency in the context of Change Laboratory interventions, which aimed to transform activities in work contexts. The five interconnected elements of agency are (i) resistance to the interventionist or management, (ii) explication of new possibilities or potentials in the activity, (iii) envisioning of new patterns or models of the activity, (iv) commitment to concrete actions, and (v) the taking of consequential actions to change the activity. To support and/or extend these previous findings related to particular types of intervention, further studies are needed to address the forms of professional agency related to organizational development in other kinds of work-related intervention. In this paper, we investigate the manifestations of and frames for professional agency during a work conference intervention. In our investigation, we primarily utilize the sociocultural notions of agency that are presented in the next section.

\section{Professional agency in interactional practice}

Within the sociocultural framework, agency is seen broadly as socioculturally mediated. Moje and Lewis (2007) define agency as the strategic making and remaking of identities, activities, relationships, cultural tools, and resources as embedded within relations of power. More precisely, agency within the sociocultural framework is mostly conceptualized and examined through three ways in local interactions.

First, agency is often linked to certain phenomena, such as the power to transform objects of activity. This kind of agency is often conceptualized as transformative, which includes breaking away from a given frame of action or traditional taken-for-granted practices or courses of action and the taking of initiatives to transform them (Engeström, 2005; Rajala et al., 2013; Virkkunen, 2006). In the best case, starting to question and problematize existing work practices and ways of working as well as making suggestions and proposing ideas for their transformation can create new innovative ideas and transformations in work practices. Transformative actions can also be realized in terms of the adoption of new positions in a professional community and through self-change (Lipponen \& Kumpulainen, 2011; Rainio, 2008). Second, agency refers to resistance to and transformation of dominant power relations (Lipponen \& Kumpulainen, 2011; Rainio, 2008). Agency does not always mean positive participation in and contribution to a shared activity; rather, it can also be manifested via resistance, opposition, withdrawal, omission, and the violation of power relations.

Third, one form of agency is conceptualized as relational agency (Edwards, 2005; Edwards \& D'Arcy, 2004). This involves the capacity to align one's thoughts and actions with those of others in order to interpret problems of practice and to respond to those interpretations and the capacity to engage with the dispositions of others in order to interpret and act on the object of joint actions in enhanced ways. In a sense, relational agency means that people are able to deal with and interpret social practices and activities from the viewpoint of others. Relational agency also refers to the act of seeking opinions from others, which also creates opportunities for learning about and understanding others' views (Rajala et al., 2013). 
In researching agency in interactional practices, it is possible to investigate the forms of agency, including the ways in which a person acts or refrains from acting and the way in which their action contributes to joint actions in the professional community. However, it makes sense not only to address how a person initiates an idea but also to explore how the action is accepted, elaborated, questioned, challenged, or ignored (Gresalfi et al., 2009). More precisely, a person's agentic voices during interaction can be addressed in terms of initiating an idea, agreeing with, elaborating on, questioning, or disagreeing with what someone else has initiated, as well as refraining from responding (Gresalfi et al., 2009). Similarly, if dialogical tensions emerge, it is meaningful to address participants' reactions to them (Rainio 2008), which can include adaptation through passivity and acceptance of the situation; resistance and rejection, which can result in withdrawal from the activity and closing oneself off; or some actions between these extremes.

In elaborating professional agency, besides investigating individuals' actions and how they are reacted to and recognized in interactions as well as their shared contribution to a joint action, it is important to take notice of the variations in subjects' participation and how such participation is framed. In this case, attention can be focused on the following questions: Who is the strongest or most visible actor? Who is the most invisible or passive actor? Who has the position of being the knower (whose knowledge counts) and decision maker (whose word counts)? In the case of dialogical tensions, what is most important is whose ideas are continuously supported or whether they are resisted or withdrawn. Who notices others' views, engages with the dispositions of others, and asks for others' opinions and who sticks to their own views without extending their own perspective? Discussion and examination of these questions are essential if we are to understand how and why the development of work organizations fails or succeeds, who has the greatest power to influence the direction and trajectory of organizational development, and what these influential actions are.

\section{Aim and Research Questions}

We examine the manifestations of professional agency in the context of work conference intervention involving situations in which the participants represent the same professional group and the participants encompass representatives from different professional groups. In our investigation, we further seek to identify how professional positions frame agency in multi-professional interactional situations. More specifically, we ask:

1. How is professional agency manifested in a work conference within and between professional groups working in a hospital context?

2. How are the manifestations of professional agency attached to professional positions?

\section{Methods and Participants}

\section{Work conference for creating a dialogical space}

This paper is part of a larger research project (PROAGENT_-Promoting Professional Agency in Education and Healthcare Work) that examines the practice of professional 
agency and ways to promote it through different practice-based interventions in Finnish education and healthcare organizations. Here, our focus is on the manifestations of and frames for professional agency in the context of practice-based work conference intervention implemented in the hospital context. In order to develop work practices in the organization, the intervention was used to create a dialogical space for the promotion of collective professional agency through small group and plenary discussions (Kalliola \& Mahlakaarto, 2011).

In the implementation, the work conference method that was originally developed by Gustavsen (Gustavsen \& Engelstad, 1986) was applied. This choice fits with the Nordic action research tradition, which is interested in engaging with reflective subjects in the field to create meaningful results that are beneficial for all actors involved while using research methods that respect and develop democracy (Hasle \& Sørensen, 2013). In light of the number of experiences using this method in Finnish working life development research (e.g., Lehtonen \& Kalliola, 2008), our aim was to offer dialogical spaces for the participants in the work community amid organizational developmental work, together with the possibility to learn from each other's experiences and to reflect on them in crafting a shared future vision of their work and work organization (Kalliola \& Nakari, 2007). To gain a democratic and dialogical space, the method suggests specific ground rules that are introduced as guidelines for dialogue (Gustavsen, 2001). These include, for example, the following: dialogue is based on a principle of give and take, not on one-way communication; all participants have the same status in the dialogue arenas; and the dialogue produces agreements that can lead to practical implications. In particular, the rules aim to reduce status and foster equal power relations between the participants. It is important to create equal spaces to develop work and organizational practices (see also Alasoini, 2011) because power relations and traditional subject positions act as major constraints on professional agency (Collin et al., 2010; Hökkä et al., 2010; Vähäsantanen et al., 2009).

\section{Implementing a work conference in a hospital organization}

The intervention was implemented in a regional emergency unit, comprising an outpatient clinic and a ward, at a Finnish central hospital organization. With approximately 90,000 patient visits per year, the emergency unit is large and hectic. The work of the physicians, nurses, and secretaries is organized in shift work, and the administrative personnel and the managers' work during office hours. Apart from the personnel, the unit has a large number of physicians working in duty service.

The work conference was organized by the research team and led by an interventionist. For the planning and implementation of the work conference, a representative steering group was established that consisted of representatives from all of the professional groups and hierarchical levels of the work unit. In addition, the interventionist and representatives of the research team participated in the steering group. At the planning stage of the intervention, the task of the steering group was to decide on the theme of the work conference. The meaningfulness and relevance of the theme for all personnel, in line with the development efforts of the organization, were highlighted. The steering group came together once to decide on the theme, and in the meeting, several suggestions for the theme from each professional group were presented and a lively 
Figure I: Contents of work conference phases.

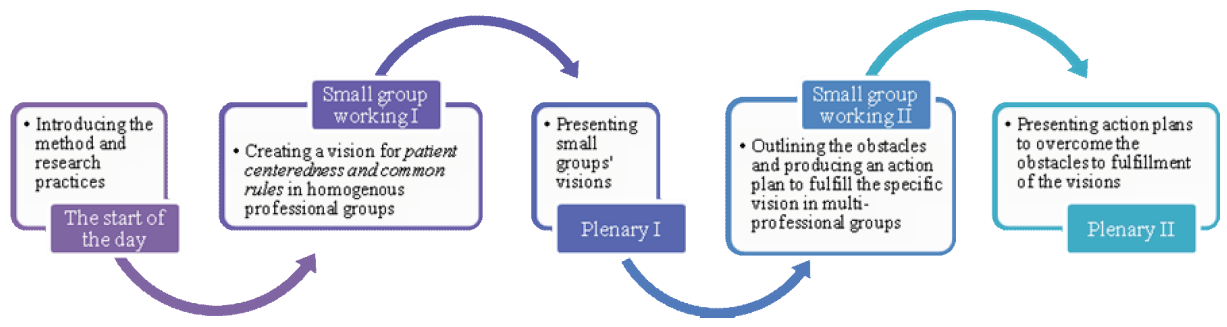

discussion continued after the meeting. It was eventually decided that the theme for the work conference would be Patient Centeredness and Common Rules. The steering group considered different professional viewpoints on the theme in the discussion.

The intervention was implemented during one working day (5 hours) in Spring 2013. The day started with a joint opening session that introduced the research project, the work conference method, and the ground rules. The ethical aspects of data collection and voluntary participation were also presented. Because of the short time available for the intervention, it was not possible to use the original structure for the organization of such a work conference (Lehtonen, 2004). Instead, the work conference consisted of two small-group working sessions and two joint plenary working sessions with specific aims (see Fig. 1). A total of 27 members of emergency unit personnel (including managers) participated in the work conference, with professional groups of the secretaries, nurses, physicians, and nursing administration being represented. During the intervention, the researchers acted as observers.

In the first small-group phase, the five professionally homogeneous groups worked on creating their vision for the theme of the day. The participants were divided into small groups in advance, according to professional position. In the first plenary session, the groups of secretaries, nurses (two groups), physicians, and the nursing administration presented their visions based on the discussions from the small groups. The aim of the plenary was to give voice to all the professional groups of the unit and to offer space to hear the outputs of the others.

For the second small-group phase, five multi-professional groups were created, three of which included physicians, nurses, secretaries, and nursing administration personnel but two in which secretaries were missing due to the numbers of the secretaries participated. Each group worked on one of the visions presented in the first plenary session. The aim was to outline the obstacles of the vision and to work on action plans for the development of work practices. Again, the results of the small-group dialogues were presented and shared with all the participants in a plenary session. As a result of the day, five different action plans were created and presented, and all these materials were later distributed to the participants and steering group members. The decisions required to realize the plans in the work unit were allocated to the steering group for future work.

\section{Research data and analysis}

The research data consisted of audio recordings (11 hours) of the small-group discussions and video recordings of the plenary sessions ( 2 hours). Because of a malfunction 
in the audio recordings, our analysis eventually focused on the discussions of the four homogeneous groups and the four multi-professional groups. The written material produced by the small groups was also utilized in the analysis, but the analytical process focused on the transcribed material from the audio and video recordings. Altogether, 150 pages of text were compiled.

The aim of the analysis was to search for different forms of professional agency and agentic voices illustrating these forms in the small-group discussions. In the homogeneous small groups, the aim was to examine different forms of agency as they emerged while producing the visions. In the analysis of the multi-professional small groups, the focus was more on how the visions created in the homogeneous groups were worked on and by whom. We were especially interested in how the members of the different professional groups participated in the discussion and what this participation and collaboration was like. In this investigation, we addressed how professional positions were attached to manifestations of professional agency.

Qualitative content analysis was applied in order to identify the manifestations of professional agency (Hsieh \& Shannon, 2005). The analysis for the data was conducted inductively in dialogue with previous theoretical conceptualizations on professional agency and with insights from the data on hand. At the first stage of analysis, we coded the discussions to identify the different kinds of agentic voices of professional agency expressed in discussions. We also categorized agentic voices and named categories by utilizing previous conceptualizations. For example, agentic voices, such as questioning existing work practices and proposing novel ideas for developing work practices, were coded and finally placed under transformative agency, which was one of the four main categories to illustrate professional agency. In addition, we undertook ethnographic analysis of the key incidents (Emerson, 2004) to illustrate the manifestations of professional agency and how these manifestations were framed by professional positions in the multi-professional small-group discussions.

We also followed the trails of visions created in the first small groups through the second small-group session and the two plenaries. Our purpose was to demonstrate how the visions were created and their evolution alongside the intervention, for example, who supported and/or resisted the vision and why? In our investigation, we found that different manifestations of and frames for professional agency emerged particularly strongly while creating vision in the homogeneous group of the secretaries, and these were discussed in two plenaries and a multi-professional small-group working session. Therefore, in the next section, the vision created in the homogeneous group of the secretaries is more closely described.

\section{Findings}

\section{Working in homogeneous groups (Small-group Working I)}

The aim of the professionally homogeneous small groups was to create a vision in the larger frame of Patient Centeredness and Common Rules in the emergency unit. The description of the forms of agency is summarized in Tab. 1.

In the homogeneous small-group work, discussions took place mainly in the consensus of like-minded employees. A number of transformative forms of professional 
Table I Forms of professional agency in the homogeneous professional groups

\begin{tabular}{|c|c|c|c|c|}
\hline $\begin{array}{l}\text { Form of } \\
\text { Agency }\end{array}$ & Secretaries & Physicians & Nurses & $\begin{array}{l}\text { Nursing } \\
\text { Administration }\end{array}$ \\
\hline Transformative & $\begin{array}{l}\text { A number of new } \\
\text { suggestions for } \\
\text { developing multi- } \\
\text { professional work } \\
\text { practices (e.g., } \\
\text { new practice of } \\
\text { nurse-secretary } \\
\text { working pairs). }\end{array}$ & $\begin{array}{l}\text { A number of } \\
\text { suggestions for } \\
\text { developing work } \\
\text { practices (e.g., shared } \\
\text { codes for behavioral } \\
\text { etiquette). }\end{array}$ & $\begin{array}{l}\text { Only a few sugges- } \\
\text { tions for develop- } \\
\text { ing fast and precise } \\
\text { patient care (e.g., } \\
\text { electronic database } \\
\text { on every patient's } \\
\text { anamnesis). }\end{array}$ & $\begin{array}{l}\text { To some extent, } \\
\text { suggestions for how } \\
\text { to develop appropri- } \\
\text { ate patient care } \\
\text { (e.g., commitment } \\
\text { to friendly patient } \\
\text { service). }\end{array}$ \\
\hline Responsive & $\begin{array}{l}\text { Plenty of agreeing } \\
\text { with, detailing, and } \\
\text { expanding of } \\
\text { questions (e.g., } \\
\text { working in pairs } \\
\text { accomplished and } \\
\text { physical spaces). }\end{array}$ & $\begin{array}{l}\text { Plenty of agreeing } \\
\text { with, commenting, and } \\
\text { sharing of experiences } \\
\text { and clarifying of ideas, } \\
\text { some detailing and } \\
\text { expanding questions. }\end{array}$ & $\begin{array}{l}\text { Plenty of agreeing } \\
\text { with, detailing, and ex- } \\
\text { panding of questions } \\
\text { concerning exist- } \\
\text { ing work practices } \\
\text { (e.g., information flow } \\
\text { between the clinic and } \\
\text { the ward). }\end{array}$ & $\begin{array}{l}\text { Plenty of defining } \\
\text { and particularizing } \\
\text { of the presented } \\
\text { vision (e.g., need for } \\
\text { training). }\end{array}$ \\
\hline Relational & $\begin{array}{l}\text { Plenty of taking } \\
\text { stances from the } \\
\text { viewpoint of all } \\
\text { professional } \\
\text { groups and } \\
\text { patients. }\end{array}$ & $\begin{array}{l}\text { Creation of vision } \\
\text { from the patient's } \\
\text { perspective (reason- } \\
\text { ing how physicians } \\
\text { could also benefit } \\
\text { from the vision). }\end{array}$ & $\begin{array}{l}\text { Plenty of exploration } \\
\text { of work practices, } \\
\text { especially from the } \\
\text { viewpoints of patients } \\
\text { and relatives, plus } \\
\text { from a multi-profes- } \\
\text { sional viewpoint. }\end{array}$ & $\begin{array}{l}\text { Plenty of relational } \\
\text { agency at the general } \\
\text { level. The vision } \\
\text { is self-evidently } \\
\text { accepted by all } \\
\text { professionals. }\end{array}$ \\
\hline Resisting & $\begin{array}{l}\text { Little resistance, } \\
\text { mostly in the } \\
\text { form of } \\
\text { questioning. }\end{array}$ & $\begin{array}{l}\text { Some resistance to } \\
\text { questioning of and } \\
\text { disregard for the } \\
\text { suggestions presented } \\
\text { (e.g., nurse-physician } \\
\text { working pairs). }\end{array}$ & $\begin{array}{l}\text { Resistance to the role } \\
\text { division within the } \\
\text { small group (e.g., who } \\
\text { will present the vision } \\
\text { in a plenary). }\end{array}$ & No resistance. \\
\hline
\end{tabular}

agency emerged in the groups. By transformative agency, we refer to ways of questioning and problematizing the existing work practices and ways of working as well as ways of making suggestions and proposing ideas for transforming them into innovative ideas and transformations in work practices (see, e.g., Virkkunen, 2006); in this intervention, they are visions. On the basis of our analysis, the groups of secretaries and physicians displayed the most initiative and were most productive in presenting proposals and ideas on how to develop the practices of the emergency unit. In addition, the physicians presented innovative ideas and had critical discussions of existing practices without them ending up as visions. Similarly, the nurses and administrative groups presented suggestions for the development of work practices, but their initiatives did not evolve to concrete visions when compared with those of the secretaries. The nurses heavily criticized the information flow and the lack of communication 
between physicians and nurses, but because they did not include this in a vision, the suggestion was not presented or developed in the later sessions of the work conference. All the visions created in the homogeneous small groups are presented in Appendix 1. Transformative agency is a necessary condition for the development of work practices; without transformative agency, there are no innovative ideas and visions to work on.

In all the homogeneous small groups, there were many responsive forms of agency. Responsive agency refers to the different ways in which presented ideas are accepted, elaborated upon, or supported (cf. Gresalfi et al., 2009). In the discussions, responsiveness emerged, for example, as agreement and with detailing and expanding on questions concerning the suggested visions. This responsive agency is important for keeping the innovative ideas on stage and ongoing. Without agreement and supporting voices, the ideas are ignored for the rest of the developmental process.

The relational form of agency in the homogeneous small groups aimed at justifying previously presented suggestions from the point of view of others (see Edwards, 2005; Edwards \& D'Arcy, 2004). Relational accounts were introduced, especially from the viewpoints of other professional groups and patients. Although relational agency was present in all groups, its focus seemed to differ. More than in other professional small groups, the nurses' relational voices included patients and relatives. Nurses showed up as patients' trustees in the system. A number of relational voices were also present in the nurses' group when it came to collaboration and information flow between the emergency clinic and the emergency ward concerning care processes. The viewpoint of patients was also present in the discussions in the small groups of secretaries and physicians. In addition, secretaries mostly argued for their vision from the perspective of all the professional groups. In the nursing administration group, relational agency emerged naturally as the vision was focused on good patient care, the issue that affected all professionals in the unit.

In the small-group discussions, resisting agency included questioning and ignoring voices on the suggestions presented. Resisting agency was most visible in the physicians' small group. Physicians often questioned the presented suggestions that related to existing work practices or simply ignored them, especially with regard to collaboration between physicians and nurses. In the secretaries' group, resistance mostly emerged in terms of questioning and assessing the "goodness" of presented ideas. The nurses' resistance was mainly focused on the roles inside the group, for example, who was going to present the vision in the plenary (cf. Engeström, 2011). In contrast to the other small groups, the discussion among the nursing administration personnel was particularly like-minded. Resisting voices seemed to hinder the documentation of ideas and thus their use in crafting work practices. Resisting voices supported existing work practices and existing relations between different professionals in the work organization, for example, in cases where collaboration between nurses and physicians were ignored.

In summary, a total of four different forms of professional agency were manifested in the homogeneous small groups. To illustrate the overlapping nature of the different forms, an extract from the group of secretaries is presented below in Table 2. In accordance with the aim of homogeneous small-group work, the extract shows how the created proposals are collectively crafted and developed. 
Table II Data extract about creating a vision in the secretaries' homogeneous group

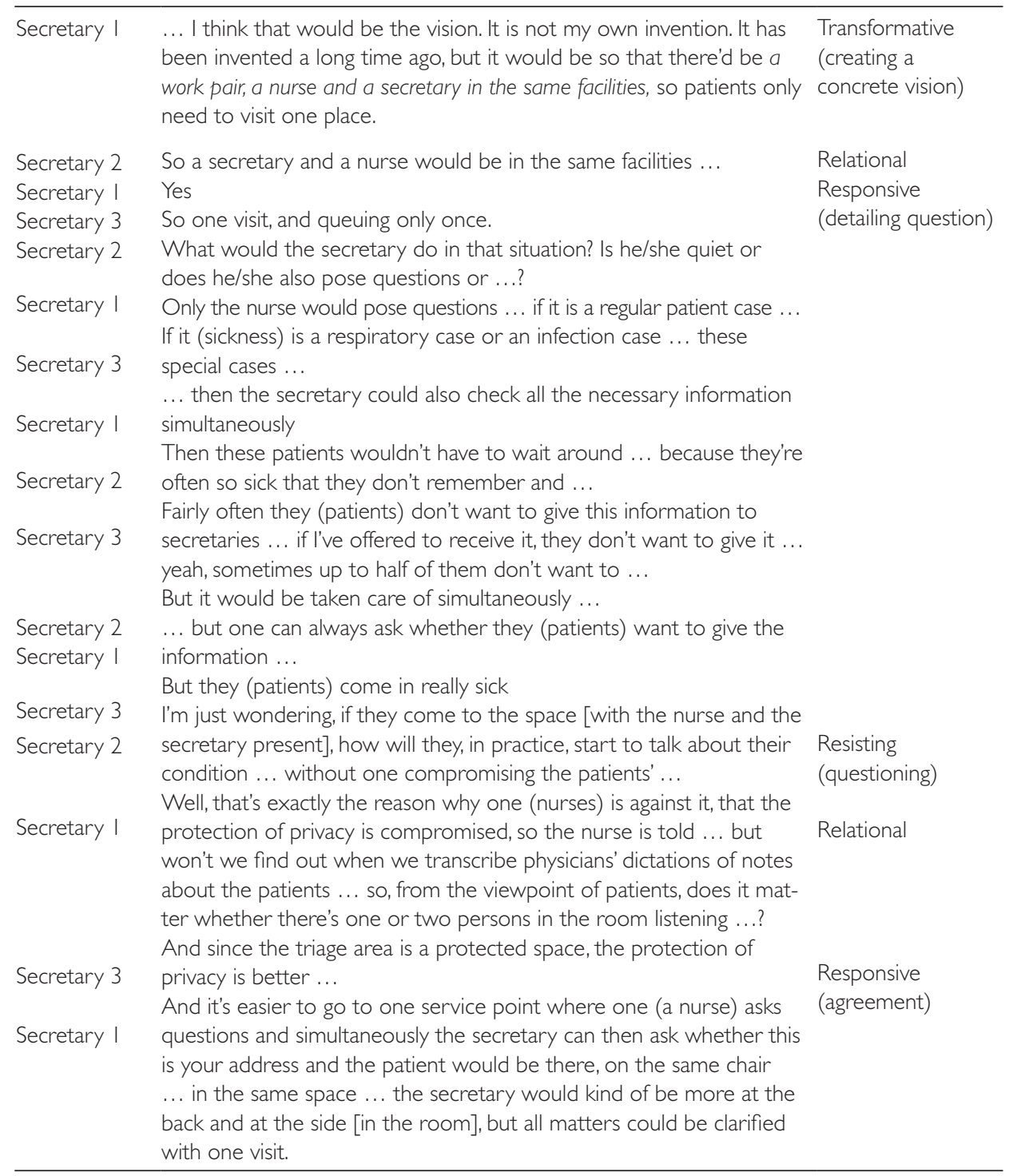

\section{Plenary One}

The aim of the first plenary was to provide space for each professional group to present their vision. In the plenary, the visions created in the homogeneous small groups were presented (see Appendix 1). Compared with the small-group working sessions, only a few forms of professional agency were present. After the presentation of each vision, 
which encompassed the introduction of the issues included in the vision as well as the justifications for them, a few clarifying questions and comments were presented. In this case, the responsive agency of the participants included answering the questions and comments. In addition to this, responsive agency (including agreeing and supporting others' visions) was mainly exercised by the physicians, while the nurses and the secretaries were quiet. For example, head physician pointed out that the vision created by the secretaries was novel and worth developing further. Interestingly, no resisting agency was present in the plenary. All this seemed indicative of the presence of the hierarchical and discursive power relations within a hospital context.

\section{Working in multi-professional groups (Small-group Working II)}

Next, we focused on the development of the visions in the multi-professional groups. The small groups had a task of outlining the obstacles for a certain vision and creating an action plan for the development of work practices according to the theme. Characteristic of this working phase in all small groups was that a reasonable amount of time was spent on discussing and clarifying the vision without arriving at any specific action plan. It seemed to be difficult to understand and work on a less familiar vision created by a certain professional group, and consequently, it took time to explore the vision before it was possible to clarify obstacles and action plans for the vision.

Our focus centered on what happened to the visions and who among the professional members exercised agency in the multi-professional small groups. Three of these small groups consisted of the representatives of all participating professional group members (physicians, nurses, secretaries, and administrative personnel). The group working on the vision created by the physicians did not have a secretary member. The forms of professional agency manifested in the multi-professional small-group working sessions are summarized in Tab. 3 according to the visions they worked on.

Another aim for this phase of the intervention was to create an action plan for the development of patient centeredness and common rules in the work unit. A more general aim was thus to develop prevailing work practices parallel with the theme of the conference. This aim was not totally achieved from the perspective of crafting the vision. Instead, the original vision was transformed into different aims concerning multiprofessional collaboration. Similarly, the obstacles for the vision were handled on the basis of these transformed ideas.

Much like the work in the homogeneous small groups, transformative, responsive, relational, and resisting agencies were present in the multi-professional small-group discussions. However, resisting agency was exercised more often in the multi-professional small-group discussions than in the homogeneous small groups. In the multi-professional groups, transformative agency was present in the discussions concerning the vision-related issue and was most visibly exercised in the group working on the secretaries' vision, while in other groups, only a few suggestions were made to develop the visions into action plans. Responsive agency was manifested in all small groups in the form of agreements, commenting, and sharing voices. Relational agency was present in the groups working with the secretaries' and nursing administration's vision from the perspective of all the professional groups. By contrast, in the groups working with the physicians' and nurses' visions, relational agency mostly emerged from the point of view of their own 
Table III Forms of agency exercised by professionals in the multi-professional groups

\begin{tabular}{|c|c|c|c|c|}
\hline $\begin{array}{l}\text { Forms and } \\
\text { professional } \\
\text { actors of pro- } \\
\text { fessional agency }\end{array}$ & Secretaries' vision & Physicians' vision & Nurses' vision & $\begin{array}{l}\text { Nursing } \\
\text { administration's } \\
\text { vision }\end{array}$ \\
\hline $\begin{array}{l}\text { Manifestations } \\
\text { of transforma- } \\
\text { tive } \\
\text { agency } \\
\end{array}$ & $\begin{array}{l}\text { A few suggestions } \\
\text { for the develop- } \\
\text { ment of the vision } \\
\text { (e.g., role breaking; } \\
\text { physician could write } \\
\text { himself, not always } \\
\text { a secretary), but } \\
\text { without a clear ac- } \\
\text { tion plan. }\end{array}$ & $\begin{array}{l}\text { Only a few suggestions } \\
\text { for creating an action } \\
\text { plan and for naming } \\
\text { possible constraints } \\
\text { for the vision. } \\
\text { No suggestions for the } \\
\text { development of the } \\
\text { vision. }\end{array}$ & $\begin{array}{l}\text { Structured discussion } \\
\text { on the vision at hand. } \\
\text { Only a few concrete } \\
\text { suggestions for the } \\
\text { action (e.g., inform- } \\
\text { ing the public about } \\
\text { the emergency clinic's } \\
\text { tasks). }\end{array}$ & $\begin{array}{l}\text { A few suggestions } \\
\text { made concern- } \\
\text { ing the vision (e.g., } \\
\text { patient food service } \\
\text { and information } \\
\text { flow). Discussion on } \\
\text { the obstacles but } \\
\text { not a clear action } \\
\text { plan. }\end{array}$ \\
\hline $\begin{array}{l}\text { Professional } \\
\text { actors }\end{array}$ & $\begin{array}{l}\text { Agency exercised } \\
\text { principally by the } \\
\text { physician. }\end{array}$ & $\begin{array}{l}\text { Agency spread among } \\
\text { all the participants. }\end{array}$ & $\begin{array}{l}\text { Agency mostly exer- } \\
\text { cised by the nursing } \\
\text { administration. }\end{array}$ & $\begin{array}{l}\text { Agency spread } \\
\text { evenly among the } \\
\text { participants. }\end{array}$ \\
\hline $\begin{array}{l}\text { Manifestations } \\
\text { of responsive } \\
\text { agency }\end{array}$ & $\begin{array}{l}\text { Plenty of agreement, } \\
\text { commenting, sharing } \\
\text { of experiences, and } \\
\text { detailing of ques- } \\
\text { tions. }\end{array}$ & $\begin{array}{l}\text { Plenty of agreement, } \\
\text { commenting and } \\
\text { sharing of experiences, } \\
\text { and some detailing of } \\
\text { questions. }\end{array}$ & $\begin{array}{l}\text { Plenty of agreement, } \\
\text { commenting and } \\
\text { sharing of experi- } \\
\text { ences. }\end{array}$ & $\begin{array}{l}\text { Much agreement, } \\
\text { commenting and } \\
\text { sharing of experi- } \\
\text { ences. }\end{array}$ \\
\hline $\begin{array}{l}\text { Professional } \\
\text { actors }\end{array}$ & $\begin{array}{l}\text { Agency mostly } \\
\text { exercised between } \\
\text { physician and } \\
\text { secretary. }\end{array}$ & $\begin{array}{l}\text { Agency mostly exer- } \\
\text { cised by the nurses. }\end{array}$ & $\begin{array}{l}\text { Agency mostly exer- } \\
\text { cised by the nurses } \\
\text { and the nursing } \\
\text { administration. }\end{array}$ & $\begin{array}{l}\text { Agency spread } \\
\text { evenly among the } \\
\text { participants. }\end{array}$ \\
\hline $\begin{array}{l}\text { Manifestations } \\
\text { of relational } \\
\text { agency }\end{array}$ & $\begin{array}{l}\text { Discussion took } \\
\text { place from the per- } \\
\text { spective of all the } \\
\text { professional groups. } \\
\text { Many arguments for } \\
\text { multi-professional } \\
\text { practices. }\end{array}$ & $\begin{array}{l}\text { Discussion took place } \\
\text { mostly in relation to } \\
\text { the work practices } \\
\text { of nurses and } \\
\text { physicians. }\end{array}$ & $\begin{array}{l}\text { The discussion mostly } \\
\text { took place not only } \\
\text { in relation to the } \\
\text { patients but also in } \\
\text { relation to the work } \\
\text { practices of physicians } \\
\text { and nurses (e.g., the } \\
\text { workload of physi- } \\
\text { cians). }\end{array}$ & $\begin{array}{l}\text { Discussion took } \\
\text { place from the } \\
\text { perspective of all } \\
\text { professional } \\
\text { groups. }\end{array}$ \\
\hline $\begin{array}{l}\text { Professional } \\
\text { actors }\end{array}$ & $\begin{array}{l}\text { Agency strongly } \\
\text { exercised by the } \\
\text { secretary. }\end{array}$ & $\begin{array}{l}\text { Agency exercised } \\
\text { by the nurses (e.g., } \\
\text { integrating the physi- } \\
\text { cian and physician's } \\
\text { opinions in the } \\
\text { discussion). }\end{array}$ & $\begin{array}{l}\text { Agency mostly exer- } \\
\text { cised by the nursing } \\
\text { administration. }\end{array}$ & $\begin{array}{l}\text { Agency strongly } \\
\text { exercised by the } \\
\text { secretary. }\end{array}$ \\
\hline $\begin{array}{l}\text { Manifestations } \\
\text { of resisting } \\
\text { agency }\end{array}$ & $\begin{array}{l}\text { Plenty of resisting } \\
\text { voices. }\end{array}$ & $\begin{array}{l}\text { Some oppositional } \\
\text { voices concerning the } \\
\text { suggestions for the ac- } \\
\text { tion plan and method. }\end{array}$ & $\begin{array}{l}\text { Plenty of ignoring and } \\
\text { resisting voices in the } \\
\text { group. }\end{array}$ & No resisting. \\
\hline $\begin{array}{l}\text { Professional } \\
\text { actors }\end{array}$ & $\begin{array}{l}\text { Strongest resistance } \\
\text { from the nursing ad- } \\
\text { ministration and the } \\
\text { physician groups. }\end{array}$ & $\begin{array}{l}\text { Mostly exercised by } \\
\text { the physician. }\end{array}$ & $\begin{array}{l}\text { Agency strongly exer- } \\
\text { cised by the physician. }\end{array}$ & \\
\hline
\end{tabular}


practices and patients; however, relational agency was probably realized in the form of an increased awareness of patient care from the perspective of other professionals.

Transformative, responsive, and relational agency were exercised by all professional members in multi-professional discussions (see Tab. 3); however, resisting agency was most strongly exercised by the physicians. Although this resisting agency revealed the existence of prevailing power relations in multi-professional collaboration, resisting voices did not violate but instead reproduced the existing hierarchical power relations of the hospital organization (cf. Lipponen \& Kumpulainen, 2011; Rainio, 2008). The different forms of agency and their connectedness to professional positions are illustrated in Tab. 4. In the small group, a physician, a secretary, three nurses, and a nursing administration member continued to work with the secretaries' vision (see Appendix 2). The extract is not focused on this vision but on another related theme that emerged during the discussion regarding who can order a prescription and who has the task of taking care of patients' prescriptions as a whole. The preceding discussion included the nurse's concern on the lack of information exchange between professionals when checking patient's prescriptions.

Table IV Data extract from a discussion in multi-professional group working with secretaries' vision

\begin{tabular}{lll}
\hline Secretary & But think about it, since we have to go by the [medication] list ... & $\begin{array}{l}\text { Resisting } \\
\text { (elaborating the issue) }\end{array}$ \\
\hline Physician & $\begin{array}{l}\text {... but if a physician has dictated that "according to the medica- } \\
\text { tion list", then you go by that. You don't have to "sign" it separately } \\
\text { anymore. It's futile work. }\end{array}$ & Resisting \\
\hline Nurse & $\begin{array}{l}\text { It might be futile work, but one example, if you will. A few weeks } \\
\text { ago, there was a patient who, luckily, was able to communicate him/ }\end{array}$ & (perspective of patient \\
& $\begin{array}{l}\text { herself and as for the home medication, the entry was "according } \\
\text { to the medication list." Gosh, if l'd marked it like that: the patient }\end{array}$ & and other professionals) \\
& had six lines of medication cards there, it caught my eye and I said \\
to the patient that let's check these once over. The patient said that & \\
he/she was not taking any of those medications at the time. & \\
\hline
\end{tabular}

At the beginning of the extract, the secretary exhibits strong resisting agency in opening up and questioning the practices of prescribing. She defends her idea about a prevailing defect in prescription practice. In this extract, the physician makes it clear that it is the physician's responsibility to sign the medication list whatever the situation might be, resisting the secretary's elaboration. The nurse exercised strong relational agency in explaining how important it is to check the lists specifically to see the larger picture. This nurse also took the perspectives of other professionals as well as the patient into account. In sum, on the basis of different forms of professional agency, the existing work practices remained non-crafted.

Furthermore, the physician's role was rather ambivalent in the small-group discussion concerning the secretaries' vision. The physician made creative and novel openings but also resisted and criticized the proposals of other professional members. This resistance, ultimately, actually prevented the change. The physician spoke strongly from the point of view of his own experience and work practices without perceiving the vision as 
a multi-professional effort. We thus suggest that because relational agency was not that strongly presented by the physician (representing a member of a professional group with high status), the prevailing hierarchical professional boundaries and power hierarchies typical to hospital context were not fully crossed.

\section{Plenary Two}

The aim of plenary two was to present the action plans to overcome the obstacles to the fulfillment of the vision. As in plenary one, the voices were not diverse; action plans and the obstacles for the fulfillment of the vision were presented mechanically, after which little discussion took place on how to implement the action plans or how to continue. Typically, in the second plenary, the original visions created in the homogeneous groups often vanished or were transformed into different or new issues. Much as in plenary one, the interventionist and head physician (occasionally the head nurse) seemed to exercise agency and power by commenting on the presentations. A striking characteristic was the absence of shared discussion on how to develop the vision further. This work was left to the steering group.

\section{Summarizing the trail of the secretaries' vision}

The group of secretaries seemed to be the most active in creating a vision according to phases of the conference. Furthermore, this group manifested most visibly responsive and relational forms of agency from the perspective of all the professional groups in the first small-group sessions. However, in the first plenary, the secretaries were passive in responding to their vision even though the vision was identified as novel and worth developing by the head physician. Again, in the multi-professional groups, the representative of the secretaries continued to be active and manifested several kinds of agency. The discussion continued on the basis of the secretaries' vision, followed by a few suggestions about how to develop it, but not ending up with a clear action plan. In plenary two, clear action plans were not processed either. Instead, only a few comments and questions were presented by the interventionist and the head physician. Discussion was characterized by the absence of shared discussion about the development of the visions. Consequently, our interpretation is that secretaries, in particular, manifested professional agency during the intervention, presenting concrete suggestions for developing, for instance, multi-professional practices. There may have been an uncommon opportunity for the organization to benefit and further elaborate the suggested visions. However, neither the professional groups themselves nor the steering group exploited the professional agency exercised in the intervention, which may also indicate a power presence of some professional groups.

\section{Discussion}

The analysis revealed the variety of manifestations of professional agency within and between the professional groups. Specifically, we illustrated how professional agency 
became visible in making practical suggestions (transformative agency) in the form of resisting and ignoring (resistant agency), agreeing and supporting presented proposals (responsive agency), and in relation to patients and other professional groups' practices (relational agency). The inter-relatedness of these forms was strongly intertwined with the nature of the visions that emerged and the action plans created. The meaning of professional agency has been demonstrated, for example, for employees' lifelong learning (Harteis \& Goller, 2014). Our findings further suggest that professional agency can be understood as a necessary condition for the (un)successful development of work practices. Indeed, agency can create favorable conditions for multifaceted (re)developmental efforts. Through the transformative perspective, ideas for renewal of work practices can be created. At the same time, however, resistance can obstruct the implementation of decent ideas.

The different professional groups seemed to adopt stances or positions through confrontations and suggestions for collaborative work practices. For example, new suggestions about ways to strengthen the role of all professional groups in patient care were introduced. This seems to be in line with previous studies related to sharing collaborative practices and the requirements of interprofessional work (Collin et al., 2012). Furthermore, the study showed that professional positions and power relations framed the exercise of professional agency. For instance, even if strong professional agency was exercised in the small-group working phases by all professional groups, the final decision to implement the ideas was not made by the professional groups but mostly by the management and highest quarters in the official hierarchy. For us, this showed how persistently the prevailing labor contracts and conditions (e.g., the ultimate responsibility of the physicians) framed the developmental endeavors. Consequently, these frames may also constrain involvement in development, and strong professional agency is required to be able to overcome these frames. This notion is in accordance with the findings presented in practice-based studies that have addressed the absence of a political perspective in approaching organizations (Erden et al., 2014). Social practices in organizations cannot be conceptualized as solely consensusbased; they include tensions, resistance, and struggles that emerge from inside rather than from outside the organization. This is why we have paid attention to the emergence of social practices that possibly shape and are shaped by people's power relations (Erden et al., 2014).

The intervention seemed to offer an uncommon space for exercising professional agency to some extent, especially for the members of the personnel with lower status in the formal hierarchy, in this case, the secretaries. Apart from the many positive consequences of the intervention, for instance, the opportunity for shared discussion, our analysis also made the prevailing power hierarchies visible. For example, physicians seemed to have a strong position in envisioning and/or in resisting suggested ideas and they used their voice mainly from their own profession's perspective. Consequently, the work conference arguably represented the work community on a smaller scale. On the basis of our findings, we suggest that to strengthen all professional groups' agency, the emergence of collective agency needs to be supported. It also appears important to take seriously the transformative initiatives made by the professional groups that were equipped with the determination, commitment, and ability to act (in this case, the secretaries) and to exploit them further (Eteläpelto et al., 2013). 
We can critically discuss the efforts needed to strengthen professional agency in organizations with traditional hierarchical structures and power positions among professionals (Collin et al., 2010, 2012). In relation to the method utilized in this study, we noticed that the work conference may possibly have caused the disappearance of the vision in the work of the multi-professional groups. In this case, the implementation of the method as a 1-day intervention obviously did not allow enough time for the development of the visions into concrete action plans or for the task of developing the ideas further and realizing them in the work practices, which was left to the steering group. In addition, the potential elaboration of the created visions and action plans was to be implemented on the basis of written documents only. Moreover, some of the participants acted more than others as participative agents in the intervention. To utilize the method further, it might be useful to concentrate on one selected vision in the second phase.

If we want to move forward to sustainable development and work (Hökkä \& Eteläpelto, 2014; see also Kira et al., 2010), there is a need to give all participants an opportunity to exercise strong ownership and commitment during and especially after the actual intervention and (re)invention of ideas created during the intervention. Each employee should be an active crafter of their own work practices, and thus interventions should also generate the participants' strong commitment to concrete actions and to take consequential actions to change their work practices (see also Engeström, 2011). In various developmental efforts in working life, it is essential to hear every participant's voice and to strengthen all participants' engagement in change (Alasoini, 2011). It is further important to tailor the collaborative implementation that is successful in different contexts and to learn how they are linked with other developmental on-going processes in organizations. One can also elaborate more on the importance of management's impact for the success of such interventions in hospital organization (see Mintzberg, 2012).

As the majority of the studies of professional agency have so far focused on the individual level, we want to address the importance of collective agency targeted at the development of authentic practices. We appear to be in urgent need of the concrete means to support collective agency in organizational interventions in the future. In this study, we have possibly not been able to develop an authentic picture of what is going on in the setting, for instance, after the intervention. In future work, we need to use other data collection devices, such as observations of work practices and interviews, to identify the participants' views, and to understand better the possible consequences of the intervention. Further, we need more information and empirical research on forms of professional agency in authentic work organizations. Because of the context-dependent nature of power and agency, it is important to make the relationship between them visible and to subject this relationship to general discussion.

\section{Acknowledgments}

This article was supported by the Academy of Finland (Project no. 139538). The PROAGENT research group consists of Anneli Eteläpelto, Päivi Hökkä, Katja Vähäsantanen, Susanna Paloniemi, Sanna Herranen, and Kaija Collin. 


\section{References}

Ahearn, L.M. (2001) 'Language and agency', Annual Review of Anthropology 30(1): 109-137.

Alasoini, T. (2011) 'Workplace development as part of broad-based innovation policy: exploiting and exploring three types of knowledge', Nordic Journal of Working Life Studies 1(1): 23-43.

Bandura, A. (2002) 'Growing primacy of human agency in adaptation and change in the electronic era', European Psychologist 7(1): 2-16.

Billett, S. (2011) 'Subjectivity, self and personal agency in learning through and for work', in M. Malloch, L. Cairns, K. Evans and B. O’Connor (eds), International Handbook of Workplace Learning. London: Sage, 60-72.

Billett, S. and Pavlova, M. (2005) 'Learning through working life: Self and individuals' agentic action', International Journal of Lifelong Education 24(3): 195-211.

Brown, A., Kirpal, S. and Rauner, F. (2007) (eds) 'Identities at Work'. Dordrecht: Springer.

Buch, A. and Andersen, V. (2013) '(De)stabilizing self-identities in professional work', Nordic Journal of Working Life Studies 3(3): 155-173.

Carter, M. (2002) 'Diagnosis: mismanagement of resources', OR/MS Today 29(2): 26-33.

Clegg, S. (2006) 'The problem of agency in feminism: A critical realist approach', Gender and Education 18(3): 309-324.

Collin, K., Paloniemi, S. and Herranen, S. (2015) 'INPROF - Promoting teamwork processes and interprofessional collaboration in emergency work (2010-2012)', Studies in Continuing Education Special Issue. In press.

Collin, K., Paloniemi, S. and Mecklin, J-P. (2010) 'Promoting inter-professional teamwork and learning - The case of a surgical operating theatre', Journal of Education and Work 23(1): 43-63.

Collin, K., Paloniemi, S., Virtanen, A. and Eteläpelto, A. (2008) 'Constraints and challenges on learning and construction of identities at work', Vocations and Learning 1(3): 191-210.

Collin, K., Sintonen, T., Paloniemi, S. and Auvinen, T. (2011) 'Work, power and learning in a risk filled occupation', Management Learning 42(3): 301-318.

Collin, K., Valleala, U.M., Herranen, S. and Paloniemi, S. (2012) 'Ways of inter-professional collaboration and learning in emergency work', Studies in Continuing Education 34(3): 281-300.

Edwards, A. (2005) 'Relational agency: Learning to be a resourceful practitioner', International Journal of Educational Research 43(3): 168-182.

Edwards, A. and D'Arcy, C. (2004) 'Relational agency and disposition in sociocultural accounts of learning to teach', Educational Review 56(2): 147-155.

Emerson, R.M. (2004) 'Working with 'key incidents”, in C. Seale, G. Gobo, J.F Gubrium and D. Silverman (eds), Qualitative Research Practice. London: Sage, 459-472.

Engeström, Y. (2005) 'Development, movement and agency: Breaking away into mycorrhizae activities'. Paper presented at the International Symposium 'Artefacts and Collectives: Situated Action and Activity Theory', Lyon, July 4-6.

Engeström, Y. (2011) 'From design experiments to formative interventions', Theory \& Psychology 21(5): 598-628.

Erden, Z., Schneider, A. and von Krogh, G. (2014) 'The multifaceted nature of social practices: A review of the perspectives on practice-based theory building about organizations', European Management Journal 32(5): 712-722.

Eteläpelto, A., Vähäsantanen, K., Hökkä, P. and Paloniemi, S. (2013) 'What is agency? Conceptualizing professional agency at work', Educational Research Review 10: 45-65. 
Eteläpelto, A., Vähäsantanen, K., Hökkä, P. and Paloniemi, S. (2014) 'Identity and agency in professional learning', in S. Billett, C. Harteis and H. Gruber (eds), International Handbook of Research in Professional and Practice-based Learning. Dordrecht: Springer, 645-672.

Fenwick, T. (2006) 'Escaping/becoming subjects: Learning to work the boundaries in a boundaryless work', in S. Billett, T. Fenwick and M. Somerville (eds), Work, Subjectivity and Learning. Dordrecht: Springer, 21-36.

Forsman, P., Collin, K. and Eteläpelto, A. (2014) 'The practice of professional agency and the emergence of collaborative creativity in developmental staff meetings', in C. Harteis, A. Rausch and J. Seifried (eds), Discourses on Professional Learning: On the Boundary Between Learning and Working. Dordrecht: Springer, 45-74.

Gherardi, S. (2012) 'How To Conduct A Practice-Based Study: Problems and Methods'. Massachusetts: Edward Elgar.

Glouberman, S. and Mintzberg, H. (2001) 'Managing the care of health and cure of disease part I: differentiation', Health Care Management Review 26(1): 56-69.

Gresalfi, M. Martin, T., Hand, V. and Greeno, J. (2009) 'Constructing competence: An analysis of student participation in the activity systems of mathematics classrooms', Educational Studies in Mathematics 70(1): 50-70.

Gustavsen, B. (2001) 'Theory and practice: The mediating discourse', in P. Reason and H. Bradbury (eds), Handbook of Action Research. London: Sage, 17-26.

Gustavsen, B. and Engelstad, P.H. (1986) 'The design of conferences and the evolving role of democratic dialogue in changing working life', Human Relations 39(2): 101-115.

Hager, P., Lee, A. and Reich, A. (2012) 'Practice, Learning and Change. Practice-Theory Perspectives on Professional Learning'. Dordrecht: Springer.

Harteis, C. and Goller, M. (2014) 'New skills for new jobs: Work agency as a necessary condition for successful lifelong learning', in C. Harteis, A. Rausch and J. Seifried (eds), Discourses on Professional Learning: On the Boundary Between Learning and Working. Dordrecht: Springer, 37-56.

Hasle, P. and Sørensen, O. H. (2013) 'Employees as individually and collectively acting subjects - key contributions from Nordic working life research', Nordic Journal of Working Life Studies 3(3): 9-30.

Hitlin, S. and Elder, G. H. (2007) 'Time, self and the curiously abstract concept of agency', Sociological Theory 25(2): 170-191.

Hsieh, H.-F. and Shannon, S.E. (2005) 'Three approaches to qualitative content analysis', Qualitative Health Research 15(9): 1277-1288.

Hökkä, P. and Eteläpelto, A. (2014) 'Seeking new perspectives on the development of teacher education: A study of the Finnish context', Journal of Teacher Education 65(1): $39-52$.

Hökkä, P., Eteläpelto, A. and Rasku-Puttonen, H. (2010) 'Recent tensions and challenges in teacher education as manifested in curriculum discourse', Teaching and Teacher Education 26(4): 845-853.

Hökkä, P. and Vähäsantanen, K. (2014) 'Agency-centred coupling - A better way to manage an educational organization?', International Journal of Leadership in Education 17(2): 131-153.

Kalliola, S. and Mahlakaarto, S. (2011) 'The methods of promoting professional agency at work'. Paper presented at the RWL Conference, Shanghai, December 4-7.

Kalliola, S. and Nakari, R. (2007) 'Renewing occupational culture - bridging boundaries in learning spaces', International Journal of Educational Research 46(3-4): 190-203. 
Kira, M., van Eijnatten, F.M. and Balkin, D.B. (2010) 'Crafting sustainable work: development of personal resources', Journal of Organizational Change Management 23(5): 616-632.

Lehtonen, J. (2004) (eds) 'Työkonferenssi Suomessa: vuoropuheluun perustuva työyhteisöjen kehittämismetodi' [Work conference in Finland: a dialogue-based development method of work organizations]. Raporttisarja 1 [Report series 1]. Helsinki: Työturvallisuuskeskus [The Centre for Occupational Safety].

Lehtonen, J. and Kalliola, S. (2008) (eds) 'Dialogue in Working Life Research and Development in Finland. Labour, Education \& Society 13'. Frankfurt am Main: Peter Lang.

Lingard, L., Espin, S., Evans, C. and Hawryluck, L. (2004) 'The rules of the game: interprofessional collaboration on the intensive care unit team', Critical Care 8(6): R403R408.

Lipponen, L. and Kumpulainen, K. (2011) 'Acting as accountable authors: Creating interactional spaces for agency work in teacher education', Teaching and Teacher Education 27(5): 812-819.

Mintzberg, H. (2012) 'Managing the myths of health care', World Hospitals and Health Services 48(3): 4-7.

Moje, E.B. and Lewis, C. (2007) 'Examining opportunities to learn literacy: The role of critical sociocultural literacy research', in. C. Lewis, P. Enciso and E.B. Moje (eds), Reframing Sociocultural Research on Literacy. Identity, Agency and Power. Mahwah: Lawrence Erlbaum, 15-48.

Paloniemi, S. and Collin, K. (2010) 'Workplace learning and work-related identity constructions in a clinical setting', in M. Caltone (ed), Handbook of Lifelong Learning Developments. New York: Nova, 141-161.

Pisano, G., Bohmer, R.M. J. and Edmondson, A.M. (2001) 'Organizational differences in rates of learning: Evidence from the adoption of minimally invasive cardiac surgery' Management Science 47(6): 752-768.

Rainio, A.P. (2008) 'From resistance to involvement: examining agency and control in a playworld activity', Mind, Culture and Activity 15(2): 115-140.

Rajala, A., Hilpiö, J., Lipponen, L. and Kumpulainen, K. (2013) 'Expanding the chronotopes of schooling for promotion for students' agency', in O. Erstad and J. Sefton-Green (eds), Identity, Community and Learning Lives in the Digital Age. Cambridge: Cambridge University Press, 107-125.

Ramanujam, R. and Rousseau, D.M. (2006) 'The challenges are organizational not just clinical', Journal of Organizational Behavior 27(7): 811-827.

Sohlberg, P., et al. (2007) 'Professional Expertise under Restructuring: Comparative Studies of Education and Health Care'. Report. http://www.gu.se/digitalAssets/1321/1321780_ profknow_wp3.pdf

Tomlinson, J., Muzio, D., Sommerlad, H., Webley, L. and Duff, L. (2013) 'Structure, agency and career strategies of white women and black and minority ethnic individuals in the legal profession', Human Relations 66(2): 245-269.

Virkkunen, J. (2006) 'Dilemmas in building shared transformative agency', Activités 3, $19-42$.

Vähäsantanen, K. and Eteläpelto, A. (2011) 'Vocational teachers' pathways in the course of a curriculum reform', Journal of Curriculum Studies 43(3): 291-312.

Vähäsantanen, K., Saarinen, J. and Eteläpelto, A. (2009) 'Between school and working life: Vocational teachers' agency in boundary-crossing settings', International Journal of Educational Research 48(6): 395-404.

Wrzesniewski, A. and Dutton, J.E. (2001) 'Crafting a job: Revisioning employees as active crafters of their work', Academy of Management Review 26(2): 179-201. 
Appendix I: Vision Created in the Homogeneous Groups

\begin{tabular}{ll}
\hline Nursing & An emergency patient feels that he/she has received good care and the appropriate \\
Administration & $\begin{array}{l}\text { attitudes from staff that like their work (every staff member understands the meaning of } \\
\text { good customer service, commitment, respect for each other's work, and zero tolerance } \\
\text { for bad behavior from staff, patients, or next of kin). }\end{array}$ \\
\hline Nurses & - A real emergency patient (all necessary information has been exchanged) \\
& - A patient is an individual (e.g., privacy, listening, respectful attitude from the staff, \\
& holistic care) \\
& - Communication between nurses and physicians is vital! \\
& - A patient's continuous treatment on the wards (the importance of reports between \\
& care units, holistic care) \\
\hline Physicians & Being cognizant of the mutual rules (repetition of rules; rules have to be primarily for \\
& the best of the patients; rules for behavior; commitment to rules) \\
& - Informing patients about the aim of the treatment \\
- Well-functioning facilities & Action during times of urgency (focusing on the essential; the importance of team \\
& spirit; team training for emergency situations) \\
- Forming a system for feedback & - Nurse-secretary work pair in triage \\
- The secretary is a member of the care team & Clarifying areas of responsibility, collaboration \\
- Commitment to work tasks & Supervision of work, management
\end{tabular}

\section{Appendix 2: Secretaries' Vision as Created in a Homogeneous Group and Obstacles and Action Plan Developed in a Multi-Professional Group}

\section{Vision}

Nurse-secretary work pair in triage

The secretary is a member of the care team

- Clarifying areas of responsibility, collaboration

- Commitment to work tasks

- Supervision of work, management

\section{Obstacles}

- Facilities

- Adequacy of resources

- Flow of information (e.g., during times of urgency)

- "Old habits die hard"?

\section{Plans of Action}

- Flexible job descriptions

- Flow of information between the different professional groups

- Directives to facilitate teamwork

- Courage to ask questions reciprocally

- Collaboration within the emergency unit

- Commitment to work

- Managers' responsibility and support 